\title{
ESTIMATING RELATIVE IMPORTANCE OF RESILIENCE INDICATORS FOR LARGE-SCALE HOSPITAL BUILDINGS TO WITHSTAND HYDROLOGICAL DISASTERS
}

\author{
Niyati Gupta $^{1 *}$, Anil Dewan ${ }^{2}$, Manoj Mathur ${ }^{3}$
}

${ }^{1 *}$ Research Scholar, Department of Architecture, School of Planning and Architecture, Delhi, India; ${ }^{2,3}$ Professor, Department of Architecture, School of Planning and Architecture, Delhi, India.

Email: ${ }^{1 *}$ niyatiphd218arch18@spa.ac.in, ${ }^{2}$ a.dewan@spa.ac.in, ${ }^{3}$ m.mathur@spa.ac.in Article History: Received on $27^{\text {th }}$ July 2021, Revised on $13^{\text {th }}$ August 2021, Published on $17^{\text {th }}$ August 2021

\begin{abstract}
Purpose of the study: Uninterrupted hospital services and medical functions are the keys to functional resilience to cope with mass casualties. This paper presents the important level of resilience indicators for hospital functions to withstand natural disasters.
\end{abstract}

Methodology: For the survey, 21 indicators are grouped into three domains focusing on i) general concerns of healthcare infrastructure planning ii) design and planning of hospital buildings iii) emergency service and management. The corresponding indicators were ranked on a Likert scale of 1 to 5 . The authors collected 389 responses through an online survey of the healthcare professionals including disaster management professionals, medical officers, hospital architects, planners, project managers, and engineers.

Main Findings: The data were analysed for determining the Relative Importance Index (RII) of each indicator. The top 7 indicators as an outcome of this research are: 'access to the emergency services (0.861), 'planning of refugee settlements' (0.814), 'uninterrupted supply of MEP services to critical units' (0.871), 'signages for internal circulation' (0.845), 'adaptive control, command, and communication system' (0.848), 'flexible spatial planning in case of a surge of patients'(0.813), 'ensuring availability of healthcare workers with the provision of support infrastructure' $(0.758)$.

Applications of this study: Assessment of the top indicators highlight the importance of 'flexible design' and 'access to medical functions of a hospital building'. Based on these outcomes, it is proposed to develop a numerical framework for a comprehensive design appraisal of resilient hospital buildings.

Keywords: Resilience Indicators, Hydrological Disasters, Hospital Design, Planning and Management, Measuring Resilience.

\section{INTRODUCTION}

In the developing countries, more than $95 \%$ of the deaths were occurred due to natural disasters from 1970 to 2008 . In the recent years, 77 million deaths are reported due to hydrological and climatic disasters such as floods, cyclones, glacial flooding, etc. due to unavailability of food, shelter, and healthcare (IPCC, 2012). Recording a decadal damage from 1996 to 2005 the economic losses have increased to INR 4745Cr. from INR 1805Cr. (NDMA, 2008). Since 2005, direct damage to healthcare infrastructure have been observed with the increased frequency of hydrological and climate disasters (Carballo, M., et.al., 2005). Disruption to hospital functions and medical services results in trust deficit in governance systems and exposes patients and healthcare professionals to further risks and vulnerabilities (Achour, N. et.al., 2014). Most recently, in April 2021 more than 98 hospitals were affected in Gujrat due to the effects of cyclone Tauktae followed by floods in Gujrat, India (NDMA, 2021). Hence, fostering functional resilience of hospital buildings is prudent, given the gravity of loss and damages.

The effectiveness of hospital functions is measured by the building's adaptive capacity to withstand the disasters (CDC,2018). As a precursor to achieving hospital disaster resilience, quantification of potential threats and enlisting adaptive measures for hospital functioning is crucial (Kumar, 2021). Most of the academic literature research addressed the issue of 'immediate relief' to disasters or short-term resilience. However, comprehensive attributes to ensure the long-term resilience of hospital systems are unknown (Spencer, C., et.al., 2019).

Thus, it is imperative to identify the qualitative indicators to measure the resilience of hospital buildings. In this paper, the indicators are identified through a systematic review of academic literature, disaster assessment reports, and international guidelines for hospital safety and disaster preparedness. In table 1 these indicators are categorized into 5 categories of a hospital system, a) site planning, b) building architecture, c) MEP Services, d) quality assurance e) facility and staff management.

Table 1: Resilience indicators for design, planning, and management of hospital buildings

\begin{tabular}{lllll}
\hline & Category & ID & Indicators & Source(s) \\
\hline C1 & $\begin{array}{l}\text { Site Review and } \\
\text { Master Planning }\end{array}$ & F1 & Site planning in view of slopes and drainage & $\begin{array}{l}\text { Hojat, M., 2008; Back,M.H., } \\
\text { et.al.,2010; } \underline{\text { Nekoie-Moghadam, }}\end{array}$ \\
\hline
\end{tabular}




\begin{tabular}{|c|c|c|c|c|}
\hline \multicolumn{2}{|r|}{ Category } & ID & Indicators & Source(s) \\
\hline & & $\mathrm{F} 2$ & Roads and access ways & FEMA, 2007, 2008, 2013 \\
\hline & & F3 & Area availability for refugee & $\underline{\mathrm{PAHO}, 2014 ; \underline{\mathrm{WHO}}, 2015}$ \\
\hline \multirow[t]{5}{*}{$\mathrm{C} 2$} & \multirow{5}{*}{$\begin{array}{l}\text { Built-Form and } \\
\text { Structure }\end{array}$} & $\mathrm{F} 4$ & Raised construction & FEMA, 2013; FEMA2020 \\
\hline & & F5 & Alternate entry and exit at upper levels & FEMA2013; NDMA, 2016 \\
\hline & & F6 & Accessibility of helicopters/choppers & WHO, 2014, 2015 \\
\hline & & F7 & $\begin{array}{l}\text { Flexibility of reorganizing space in case of } \\
\text { surge of patients. }\end{array}$ & $\begin{array}{l}\text { FEMA 2008, WHO, 2014, 2015; } \\
\text { Yusoff, N.et.al., } 2017\end{array}$ \\
\hline & & F8 & $\begin{array}{l}\text { Support infrastructure } \\
\text { bunkbeds) for attendants. }\end{array}$ & WHO 2014, NDMA, 2016 \\
\hline \multirow[t]{4}{*}{$\mathrm{C} 3$} & \multirow[t]{4}{*}{$\begin{array}{l}\text { Building and medical } \\
\text { Services }\end{array}$} & F9 & $\begin{array}{l}\text { Location of building services (Electricity/ } \\
\text { Water Supply/ Plumbing/ Communication/ } \\
\text { Waste). }\end{array}$ & $\begin{array}{l}\text { Jacques, C. C, et.al., 2014; } \\
\underline{2015} ; \underline{\text { NDMA, }} \text {, } 2016\end{array}$ \\
\hline & & F10 & $\begin{array}{l}\text { Uninterrupted supply of building services in } \\
\text { critical areas (ICU, Wards). }\end{array}$ & $\begin{array}{ll}\text { DHS, 2012; } & \text { Cimellaro, G. P. } \\
\text { et.al., } \underline{\underline{2016}} & \\
\end{array}$ \\
\hline & & F11 & $\begin{array}{l}\text { Decentralized (Independent) planning of } \\
\text { building services. }\end{array}$ & $\begin{array}{l}\text { Sharma, S. K.,et.al., } 2020 \\
\underline{\text { FEMA2020 }}\end{array}$ \\
\hline & & F12 & $\begin{array}{l}\text { Location of medical services (Gas supply, } \\
\text { lab equipment) }\end{array}$ & $\begin{array}{l}\text { Rodrigues Leal Moitinho } \\
\text { Almeida, M., } 2021 \mathrm{r} \\
\end{array}$ \\
\hline \multirow[t]{2}{*}{$\mathrm{C} 4$} & \multirow[t]{2}{*}{ Quality assurance } & F13 & $\begin{array}{l}\text { Capacity to accommodate a surge of } \\
\text { patients. }\end{array}$ & $\begin{array}{l}\text { Cimellaro, G. P., 2016; Liu,M. } \\
\text { et.al., } 2021\end{array}$ \\
\hline & & F14 & $\begin{array}{l}\text { Flexibility of building services to serve } \\
\text { patient surge. }\end{array}$ & Krishnan,S.,et.al, 2020 \\
\hline \multirow[t]{7}{*}{ C5 } & \multirow[t]{7}{*}{$\begin{array}{l}\text { Facility and Staff } \\
\text { Management }\end{array}$} & F15 & Emergency training and drills. & $\begin{array}{l}\text { Zhong, S., et.al., 2014; Stone, T, } \\
\text { et.al., } 2020\end{array}$ \\
\hline & & F16 & Signage for emergency movement. & $\begin{array}{l}\text { Zhong, S., et.al., 2014; Stone, T, } \\
\text { et.al., 2020; }\end{array}$ \\
\hline & & F17 & $\begin{array}{l}\text { Control, command and coordination } \\
\text { systems. }\end{array}$ & Zhong, S., et.al., 2014 \\
\hline & & F18 & $\begin{array}{l}\text { Storage space and reserves of medical } \\
\text { stockpiles and logistics. }\end{array}$ & $\frac{\text { WHO }}{\text { et.al., } 2014} \underline{2013}, 2015 ;$ Zhong, S., \\
\hline & & F19 & $\begin{array}{llr}\text { Residential } & \text { facility to accommodate } \\
\text { additional } & \text { medical/non-medical } & \text { staff } \\
\text { (Bunkers/Dormitories). } & & \\
\end{array}$ & $\begin{array}{lll}\text { Krishnan,S.,et.al, } 2020 ; & \text { WHO } \\
\underline{2013}\end{array}$ \\
\hline & & $\mathrm{F} 20$ & $\begin{array}{llll}\text { Covered/Semi Covered } & \text { spaces } & \text { for } \\
\text { temporary setups. } & & & \\
\end{array}$ & FEMA, 2013, 2020 \\
\hline & & $\mathrm{F} 21$ & $\begin{array}{l}\text { Dedicated department for disaster } \\
\text { management. }\end{array}$ & $\underline{\mathrm{PAHO}, 2014}$ \\
\hline
\end{tabular}

The measurement of resilience involves estimation of the correlation between shocks, capacities, responses, and adaptive state of the hospital functions. Thus, no single indicator can measure the true value of resilience. There is a need for analytical use of qualitative indicators for the assessment of hospital disaster resilience (TANGO, 2018). The identified 21 indicators or resilience describe qualitative aspects of hospital disaster resilience. The relevance and importance of these resilience indicators is estimated against hydrological disasters in India. The outcome of the study will assist in measuring the positive impacts on hospital functions in case of mass casualties.

\section{METHODOLOGY}

The survey method is applied to test the hypothesis in mapping the biasness of the stakeholders. It is established that a questionnaire survey provides an efficient means to measure the importance and significance of the identified factors of resilience. The steps followed in the study are presented in the following flowchart as shown in figure 1.

As illustrated in the flowchart, the survey method is used as a tool for measuring the importance level of the identified indicators of resilience. In order to remove the opinion bias of the target group, these indicators are grouped in three domains focusing on general concerns of healthcare infrastructure planning ii) design and planning of hospital buildings iii) emergency service management.

Prior to the final survey, a pilot survey was launched and 41 samples (10\% of estimated sample size) for feedback was collected. The objectives of the survey are:

a) To estimate the importance of factors that will enhance the resilience of healthcare infrastructure during floods, and

b) To measure the effect on the functionality of healthcare infrastructure and services. 
The pilot survey was targeted towards multiple-stakeholder for measuring the perception of resilient design, planning, and management of the large-scale hospitals. The suggestions offered by the responders in the pilot run was incorporated in the final survey. Data was collected across the target group of medical professionals, hospital administration staff, architects/planners, structural engineers, and building service consultants.

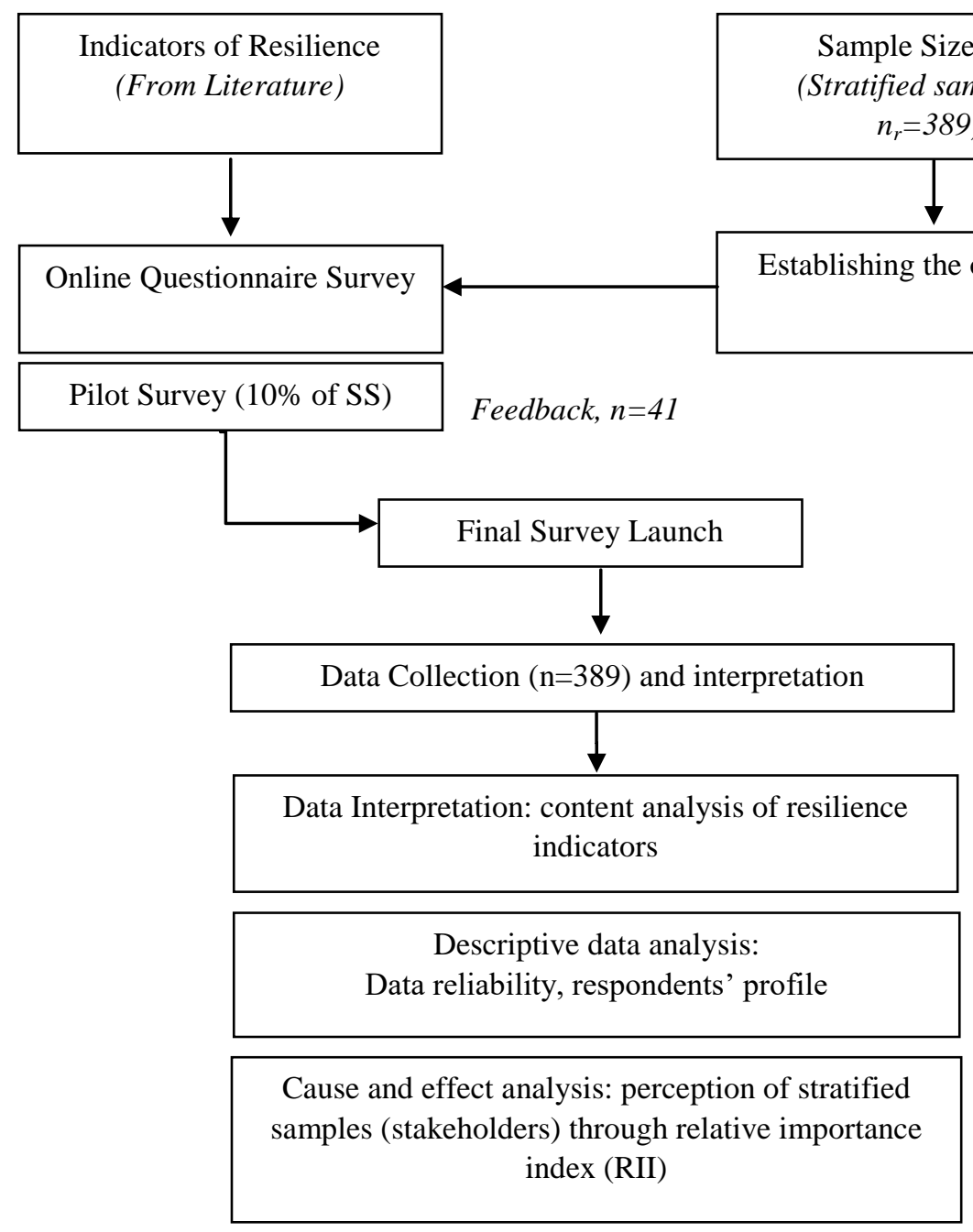

Figure 1: Methodological flowchart of data collection method of qualitative resilience indicators

\section{Sampling technique}

A stratified sampling strategy is essential to manage the number of variables. Different sample strata. The perception of different stakeholders involved in the design planning and management of healthcare infrastructure projects is to be mapped. The data collected can be further processed to estimate the importance levels and significance levels with the smaller error of estimation.

\section{Sample Size}

For a large population, a random sampling technique is generally acquired (Kotrlik, J. et.al., 2001). The sample size for the survey is measured using the 'Cochran Equation' to estimate the proportion of the population attributes.

$$
n=\frac{Z^{2} p q}{e^{2}}
$$

In equation 1:

- $\mathrm{e}$ is the desired level of precision

- $\mathrm{p}$ is the estimated proportion of the large population

- $\mathrm{q}$ is $1-\mathrm{p}$.

The $\mathrm{z}$-value is found in a $\mathrm{Z}$ table. 
This equation is adopted on a presumption of $95 \%$ confidence interval and $\pm 5 \%$ precision or margin of error. This research caters to a large population of stakeholders involved in design, planning and management of hospital buildings; hence exact universe of population cannot be determined. For this purpose, value for maximum variability is taken as $50 \%$ or 0.05 to estimate the proportion of population attributes.

\section{Statistical analysis}

This survey is designed to calculate the relative importance of the qualitative indicators of resilience of hospital buildings. The RII approach assists in confidently determine the importance of factors b) removing the redundancy of factors and relationship within the factors. It also describes specific causes and effects based on the frequency of occurrence. This frequency can be estimated using a five-point likert scale (Aibinu, A. et.al., 2002).

$$
R I I=\frac{\sum N}{A \times n}
$$

In equation 2:

RII is Relative Importance Index

$\mathrm{N}$ is the total weight given to each indicator by the respondents on the scale of 1 to 5 .

\section{Questionnaire Development}

The online questionnaire comprised of three sections of both qualitative and quantitative nature. The first sections collected the information of population strata and introduced the concept of functional resilience of hospital buildings to withstand hydrological disasters. The second section maps the broad perception of the stakeholders regarding preparedness and response regarding hospital resilience to disasters. The third part of the questionnaire is composed of two domain questions including 21 statements (resilience indicators). These indicators were ranked on a likert scale of 1 to 5 . The interpretation of the scale is expressed in the table 2 .

Table 2: Likert scale ranking of resilience indicators

\begin{tabular}{lllll}
\hline $\mathbf{1}$ & $\mathbf{2}$ & $\mathbf{3}$ & $\mathbf{4}$ & $\mathbf{5}$ \\
\hline $\begin{array}{l}\text { Not at all } \\
\text { Important }\end{array}$ & Somewhat Important & Moderately Important & Important & Most Important \\
\hline
\end{tabular}

The approach allows the author to evaluate respondent's perception and adherence towards building resilience of hospital buildings. The online questionnaire prepared using google forms was distributed to 600 plus professionals. A total of 389 responses are received at the response rate of $44.3 \%$.

\section{DATA INTERPRETATION}

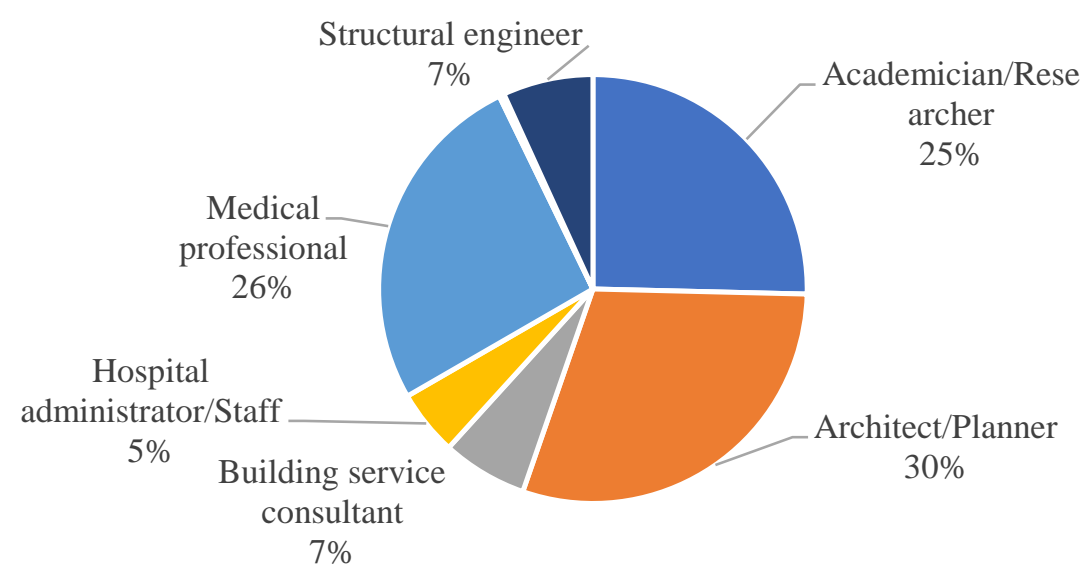

Figure 2: Description of the responders

\section{Sample strata}

Abiding the stratified sampling method, the questionnaire was circulated to 6 types of respondents. The following chart illustrates the categories of respondents.

\section{Background of the Respondent's}

Figure 3 and 4 presents $46 \%$ of the respondents have more than 10 years of work experience in the field of healthcare infrastructure management in their respective capacity. $14 \%$ of the respondents have less than 2 years of work experience, and $15 \%$ and $25 \%$ of the respondents have experience of 5 to 10 years and 2-5 years. Figure_shows that 
$61 \%$ of the respondents have undergraduate (bachelor's degree), $22 \%$ have doctoral degrees which is inclusive of MD specialization for medical professional. Lastly $17 \%$ have master's degree. In addition, $5.2 \%$ of the $61 \%$ of bachelor degree professionals have more than 10 years of experience.

$$
\begin{aligned}
& -2 \text { to } 5 \text { years } \\
& -5 \text { Less than } 2 \text { Years } 10 \text { years }
\end{aligned}
$$

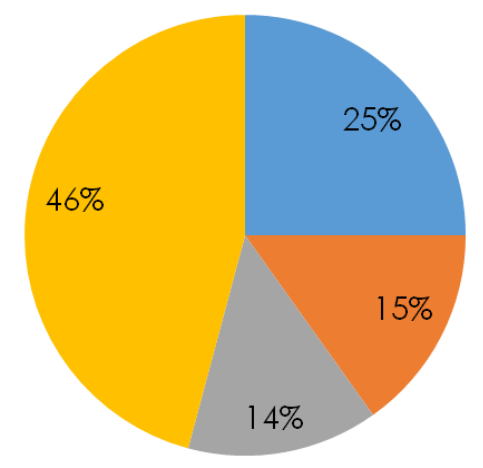

Figure 3: Work experience of the responders
Bachelors Doctoral wasters

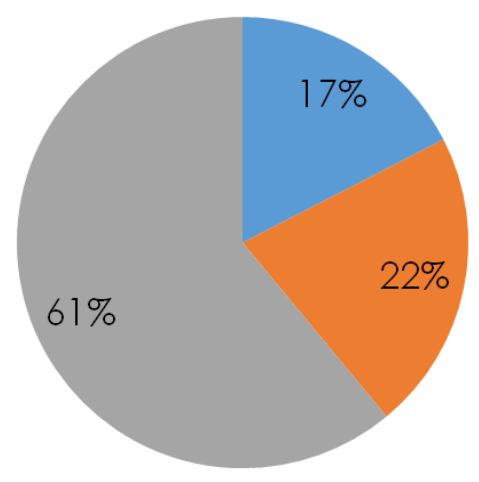

Figure 4: Education profile of the responders

Experiences of different strata of respondents are illustrated in the table below. Table 3 represents the cross- matrix to explain the work experience of the different categories of respondents.

Table 3: Sample strata: types of respondents

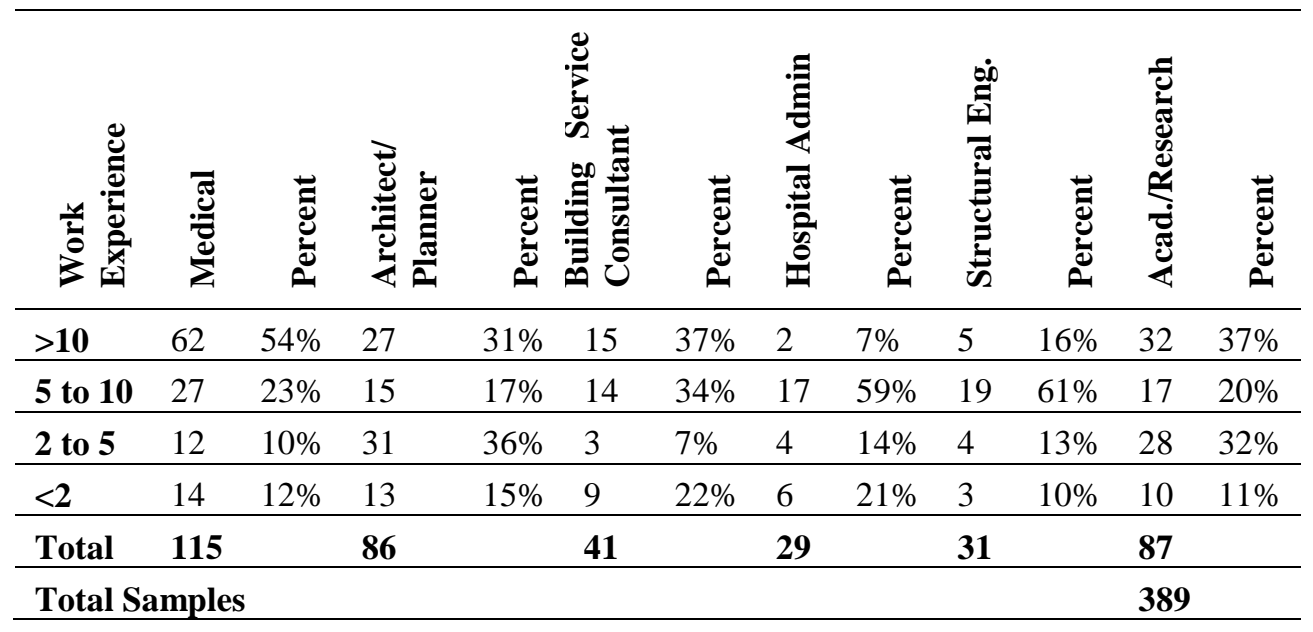

\section{ANALYSIS AND RESULTS}

\section{General concerns for Hospital Building Resilience}

The attributes identified for priority response by the stakeholders are presented in table 4 . A cross matrix for these 4 attributes is developed for checking the relative weights on the scale of 1 to 3 .

Table 4: General concerns for disaster resilient hospitals

\begin{tabular}{ll}
\hline A1 & Availability of Healthcare research centers/Trauma Center to accommodate patient surge. \\
\hline A2 & $\begin{array}{l}\text { Formulation of guidelines/policies/standards/building codes to ensure resilience of healthcare infrastructure during } \\
\text { floods. }\end{array}$ \\
\hline A3 & Rating mechanisms to ensure infrastructure resilience. \\
\hline A4 & More robust flood management plan for healthcare system. \\
\hline
\end{tabular}

In order to perform a pair-wise comparison of the above-mentioned attributes, this range gives the respondents extreme opinions and a neutral ground. Due to these extremities, level of skewedness towards stakeholders' perception can be calculated. Here, 1 is low priority, 2 is medium priority and 3 is the highest priority. The consistency of the respondents is calculated to estimate the general biasness of the stakeholders towards hospital resilience. Consistency ratio (CR) is found to be $56.6 \%$ for the data collected from all 264 respondents. The results of pair-wise comparison of the relative weights are illustrated in table 5. 
Table 5: Prioritization of Concerns regarding resilient hospital buildings

\begin{tabular}{llllll}
\hline \multicolumn{2}{l}{ Category } & Priority & Rank & $(+)$ & $(-)$ \\
\hline 1 & Availability of tertiary care centers & $55.8 \%$ & 1 & $50.4 \%$ & $50.4 \%$ \\
\hline 2 & Formulation of guidelines/policies/standards & $25.6 \%$ & 2 & $27.9 \%$ & $27.9 \%$ \\
\hline 3 & Rating mechanisms to ensure hospital resilience & $13.2 \%$ & 3 & $12.1 \%$ & $12.1 \%$ \\
\hline 4 & Robustness of disaster management plan & $5.3 \%$ & 4 & $3.8 \%$ & $3.8 \%$ \\
\hline
\end{tabular}

The top most priority is given to availability of extended facilities like refugee areas, research centres, trauma centres of hospital facilities. Thus, in order to achieve functional resilience of hospitals, adapting to new or extended healthcare facilities followed by formulating guidelines/standards/policies is prioritized in the study.

\section{Measuring RII}

Tabulation of relative importance of the resilience indicators is performed as per three broad domains:

- Concerns related to preparedness large-scale hospital buildings to withstand hydrological disasters.

- Measures considered for planning and design of hospital campuses/buildings.

- Facility management and capacity building of the medical and non-medical staff associated with hospitals.

Indicators with highest RII directly indicates that it causes maximum impact on ensuring resilience. Similarly, factor with least RII has minimum impact on resilience. Based on equation 2 used in this paper, RII is estimated using the equation 3. Table 6 presents the ranking analogy for measuring RII in equation 3.

$$
R I I=\frac{\sum 5 n+4 n+3 n+2 n=n}{A \times N}
$$

Table 6: Weightage of the importance level

\begin{tabular}{llllll}
\hline Weight & 1 & 2 & 3 & 4 & 5 \\
\hline $\begin{array}{l}\text { Weight as per importance } \\
\text { level }\end{array}$ & $\mathrm{n}$ & $2 \mathrm{n}$ & $3 \mathrm{n}$ & $4 \mathrm{n}$ & $5 \mathrm{n}$ \\
\hline Importance level & $\begin{array}{l}\text { Not at all } \\
\text { Important }\end{array}$ & $\begin{array}{l}\text { Somewhat } \\
\text { Important }\end{array}$ & $\begin{array}{l}\text { Moderately } \\
\text { Important }\end{array}$ & Important & $\begin{array}{l}\text { Most } \\
\text { Important }\end{array}$ \\
\hline
\end{tabular}

Here, $\mathrm{A}$ is the highest weight $=5$ and $\mathrm{N}$ is the total number of respondents $=389$.

RII of resilience indicators for Planning and Design of Hospital buildings

Table 5 presents the RII score of the resilience indicators responsible for functional resilience of hospital buildings. The aspects of functional resilience are drawn from site planning, structure and built form and design of building services. The responses are assessed across all the categories of stakeholders. The top 3 ranked indicators are, F10, 'Uninterrupted supply of building services in critical areas (ICU, Wards)', F9, 'Location of building services (Electricity/ Water Supply/ Plumbing/ Communication/ Waste)', and 'F1, 'Site planning in view of slopes and drainage' respectively, with maximum RII as 0.896 . The least RII of 0.745 in the entire data set is given to F6, 'Accessibility of helicopters'. As per the feedback given by the respondents, the additional cost for constructing roof area for landing of choppers and dislocation of chillers and other HVAC service on the roof, is pointed out.

Table 7: Ranking of resilience indicators for design and planning of hospital buildings

\begin{tabular}{|c|c|c|c|c|c|c|c|c|c|c|c|c|c|}
\hline 营 & 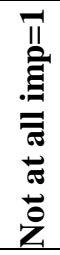 & $\mathbf{n}$ & 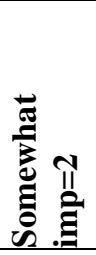 & $2 n$ & 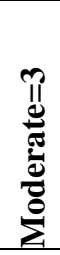 & $3 n$ & $\operatorname{Imp}=4$ & $4 n$ & 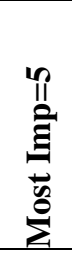 & $5 n$ & Total & RII & Rank \\
\hline F1 & 0 & 0 & 17 & 34 & 19 & 57 & 95 & 380 & 133 & 665 & 1136 & 0.861 & 3 \\
\hline $\mathrm{F} 2$ & 1 & 1 & 14 & 28 & 15 & 45 & 110 & 440 & 124 & 620 & 1134 & 0.859 & 4 \\
\hline F3 & 3 & 3 & 16 & 32 & 33 & 99 & 119 & 476 & 93 & 465 & 1075 & 0.814 & 7 \\
\hline $\mathrm{F} 4$ & 3 & 3 & 23 & 46 & 34 & 102 & 98 & 392 & 106 & 530 & 1073 & 0.813 & 8 \\
\hline F5 & 3 & 3 & 21 & 42 & 30 & 90 & 108 & 432 & 102 & 510 & 1077 & 0.816 & 6 \\
\hline F6 & 7 & 7 & 31 & 62 & 57 & 171 & 102 & 408 & 67 & 335 & 983 & 0.745 & 12 \\
\hline F7 & 2 & 2 & 16 & 32 & 38 & 114 & 115 & 460 & 93 & 465 & 1073 & 0.813 & 8 \\
\hline F8 & 5 & 5 & 24 & 48 & 58 & 174 & 111 & 444 & 66 & 330 & 1001 & 0.758 & 11 \\
\hline F9 & 0 & 0 & 14 & 28 & 18 & 54 & 94 & 376 & 138 & 690 & 1148 & 0.87 & 2 \\
\hline F10 & 1 & 1 & 11 & 22 & 16 & 48 & 68 & 272 & 168 & 840 & 1183 & 0.896 & 1 \\
\hline
\end{tabular}




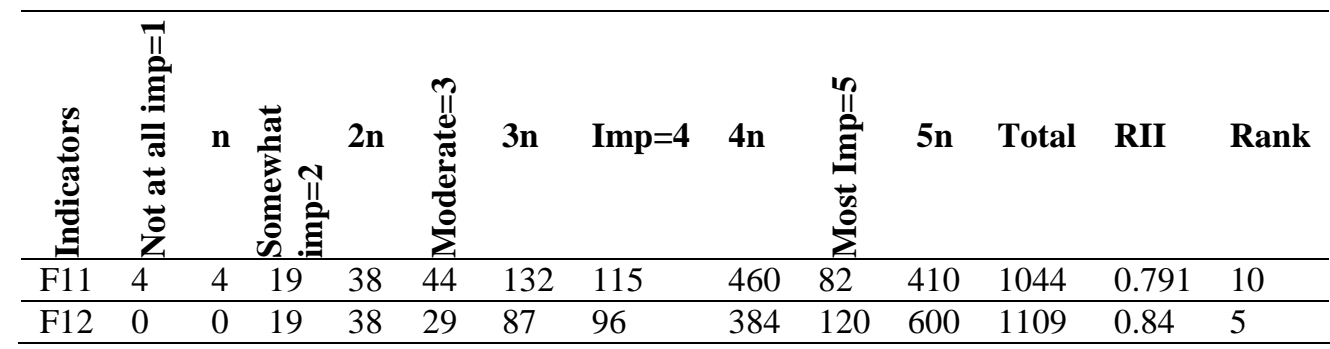

RII of resilience indicators for Facility management and capacity building

The top three measures as per the RII of the data set are, "Control, command and coordination systems", "Capacity to accommodate a surge of patients" and "Emergency training and drills". The maximum RII is 0.848 .

Table 8: Ranking of resilience indicators Facility management and Capacity building

\begin{tabular}{|c|c|c|c|c|c|c|c|c|c|c|c|c|c|}
\hline 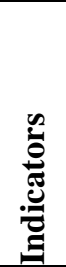 & 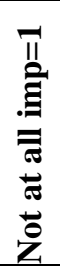 & $\mathbf{n}$ & 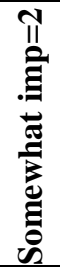 & $2 n$ & 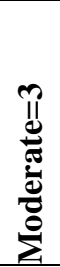 & $3 n$ & 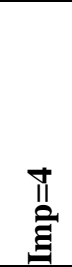 & $4 n$ & 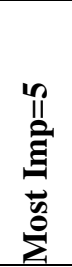 & $5 n$ & Total & RII & Rank \\
\hline F13 & 1 & 1 & 17 & 34 & 21 & 63 & 107 & 428 & 118 & 590 & 1116 & 0.845 & 2 \\
\hline F14 & 1 & 1 & 16 & 32 & 32 & 96 & 125 & 500 & 90 & 450 & 1079 & 0.817 & 6 \\
\hline F15 & 2 & 2 & 14 & 28 & 34 & 102 & 95 & 380 & 119 & 595 & 1107 & 0.839 & 3 \\
\hline F16 & 5 & 5 & 9 & 18 & 31 & 93 & 107 & 428 & 112 & 560 & 1104 & 0.836 & 4 \\
\hline F17 & 1 & 1 & 16 & 32 & 24 & 72 & 100 & 400 & 123 & 615 & 1120 & 0.848 & 1 \\
\hline F18 & 1 & 1 & 16 & 32 & 27 & 81 & 122 & 488 & 98 & 490 & 1092 & 0.827 & 5 \\
\hline F19 & 4 & 4 & 21 & 42 & 47 & 141 & 120 & 480 & 72 & 360 & 1027 & 0.778 & 8 \\
\hline F20 & 5 & 5 & 18 & 36 & 60 & 180 & 128 & 512 & 53 & 265 & 998 & 0.756 & 9 \\
\hline F21 & 5 & 5 & 22 & 44 & 47 & 141 & 84 & 336 & 106 & 530 & 1056 & 0.800 & 7 \\
\hline
\end{tabular}

\section{RII of Resilience indicators}

Perceptive importance of each resilience is measured for each stakeholder in this section. For mapping individual perception ranking of each indicator is cross referenced between the stakeholders. This calculation is done based on development of RII cross-matrix between the stakeholders and each resilience indictor. Here, RII is calculated for each indicators using equation 3 against each stakeholder. For instance, in case of medical professionals, a total samples size is 115 i.e., $\mathrm{N}=115$ and highest weight are $\mathrm{A}=5$. The same method and equation are used for all the other stakeholders. Total samples taken for the architects and planners $(\mathrm{N})=86$, Building service consultants $(\mathrm{N})=41$, Hospital administration staff $(N)=29$, structural consultants $(N)=31$ and academicians and researchers $(N)=87$. The values of $n, 2 n, 3 n, 4 n$ and $5 n$ is calculated for each resilience indicator as per the weights given by medical professionals.

Table 9 enlists the perception of relative importance of each resilience indicator as per the stratified sample set (6 stakeholders). In the overall ranking mechanism, the respondents cumulatively ranked 'Ensuring availability of healthcare workers' with maximum cumulative mean and RII. The perceived effect of each of the 21 indicators identified from the literature is evaluated based on the perceptions of the stakeholders involved in design, planning, operations and management of hospital buildings.

The top five ranked indicators are established based on RII. Ensuring availability of healthcare workers, Uninterrupted supply of building services in critical areas (ICU, Wards), Access to healthcare facilities, Location of building services (Electricity/ Water Supply/ Plumbing/ Communication/ Waste) and Site planning in view of slopes and drainage.

Most studies, as viewed in the literature review does not take into account core construction and service management into account while calculating resilience of building infrastructure. FEMA, Hospital safety guidelines, 2013 highlights certain methods of resilience against floods pertaining to flood wall construction and site planning in view of drainage and natural slopes of the site. 
Table 9: Ranking of resilience indicators as per different sample strata

\begin{tabular}{|c|c|c|c|c|c|c|c|c|c|c|c|}
\hline & & & & 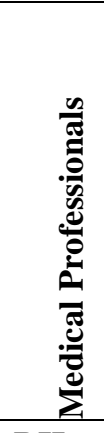 & 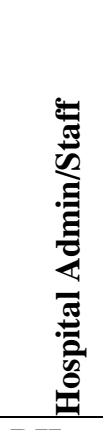 & 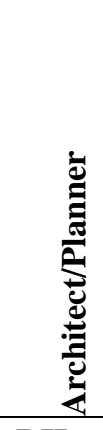 & 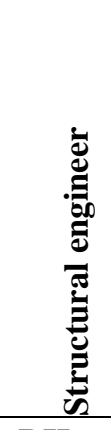 & 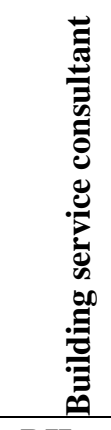 & 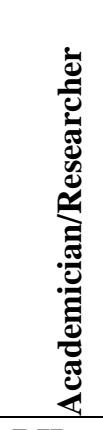 & & $\overline{\bar{\pi}}$ \\
\hline Dom & main & Id. no. & Sub-Category & RII & RII & RII & RII & RII & RII & Mean RII & $\mathbf{R}$ \\
\hline \multirow{12}{*}{ 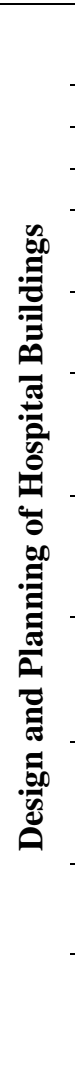 } & $\mathrm{C} 1$ & $\mathrm{~F} 1$ & $\begin{array}{l}\text { Site planning in view of slopes } \\
\text { and drainage }\end{array}$ & 0.812 & 0.892 & 0.878 & 0.856 & 0.918 & 0.872 & 0.871 & 5 \\
\hline & $\mathrm{C} 1$ & F2 & Roads and access ways & 0.829 & 0.815 & 0.884 & 0.856 & 0.871 & 0.869 & 0.854 & 9 \\
\hline & $\mathrm{C} 1$ & F3 & Area availability for refugee & 0.803 & 0.815 & 1.091 & 0.767 & 0.824 & 0.806 & 0.851 & 11 \\
\hline & $\mathrm{C} 2$ & $\mathrm{~F} 4$ & Raised construction & 0.780 & 0.877 & 0.828 & 0.778 & 0.871 & 0.812 & 0.824 & 18 \\
\hline & $\mathrm{C} 2$ & F5 & $\begin{array}{l}\text { Alternate entry and exit at } \\
\text { upper levels }\end{array}$ & 0.832 & 0.862 & 0.815 & 0.778 & 0.835 & 0.779 & 0.817 & 20 \\
\hline & $\mathrm{C} 2$ & F6 & $\begin{array}{l}\text { Accessibility } \\
\text { helicopters/choppers }\end{array}$ & 0.754 & 0.815 & 0.744 & 0.667 & 0.741 & 0.728 & 0.742 & 26 \\
\hline & $\begin{array}{l}\mathrm{C} 2 \\
\end{array}$ & F7 & $\begin{array}{l}\text { Flexibility of reorganizing } \\
\text { space in case of surge of } \\
\text { patients. }\end{array}$ & 0.791 & 0.877 & 0.823 & 0.778 & 0.859 & 0.809 & 0.823 & 19 \\
\hline & $\mathrm{C} 2$ & F8 & $\begin{array}{lrr}\begin{array}{l}\text { Support } \\
\text { benches, }\end{array} & \text { bunktructure } & \text { (eg: } \\
\text { attendants. } & & \text { for } \\
\end{array}$ & 0.748 & 0.785 & 0.752 & 0.689 & 0.800 & 0.776 & 0.758 & 25 \\
\hline & $\mathrm{C} 3$ & F9 & $\begin{array}{l}\text { Location of building services } \\
\text { (Electricity/ Plumbing/ } \\
\text { Communication/Waste). }\end{array}$ & 0.843 & 0.846 & 0.863 & 0.844 & 0.929 & 0.901 & 0.871 & 4 \\
\hline & $\mathrm{C} 3$ & F10 & $\begin{array}{l}\text { Uninterrupted supply of } \\
\text { building services in critical } \\
\text { areas (ICU, Wards). }\end{array}$ & 0.852 & 0.877 & 0.922 & 0.856 & 0.918 & 0.919 & 0.891 & 2 \\
\hline & $\mathrm{C} 3$ & F11 & $\begin{array}{l}\text { Decentralized (Independent) } \\
\text { planning of building services. }\end{array}$ & 0.739 & 0.846 & 0.681 & 0.789 & 0.894 & 0.818 & 0.795 & 22 \\
\hline & $\mathrm{C} 3$ & F12 & $\begin{array}{l}\text { Location of medical services } \\
\text { (Gas supply, lab equipment). }\end{array}$ & 0.809 & 0.908 & 0.863 & 0.789 & 0.918 & 0.827 & 0.852 & 10 \\
\hline \multirow{8}{*}{ 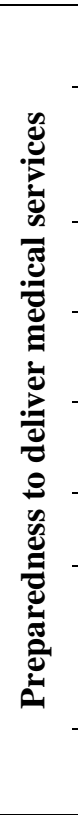 } & $\mathrm{C} 4$ & F13 & $\begin{array}{l}\text { Capacity to accommodate a } \\
\text { surge of patients. }\end{array}$ & 0.771 & 0.908 & 0.884 & 0.856 & 0.847 & 0.872 & 0.856 & 8 \\
\hline & $\mathrm{C} 4$ & F14 & $\begin{array}{l}\text { Flexibility of building services } \\
\text { to serve patient surge. }\end{array}$ & 0.757 & 0.877 & 0.841 & 0.844 & 0.788 & 0.842 & 0.825 & 16 \\
\hline & $\mathrm{C} 5$ & F15 & Emergency training and drills. & 0.832 & 0.908 & 0.833 & 0.800 & 0.871 & 0.842 & 0.847 & 12 \\
\hline & $\mathrm{C} 5$ & F16 & $\begin{array}{l}\begin{array}{l}\text { Signage for } \\
\text { movement. }\end{array} \\
\end{array}$ & 0.826 & 0.877 & 0.856 & 0.822 & 0.847 & 0.815 & 0.840 & 13 \\
\hline & $\mathrm{C} 5$ & F17 & $\begin{array}{l}\begin{array}{l}\text { Control, command } \\
\text { coordination systems. }\end{array} \\
\text { s. and } \\
\end{array}$ & 0.823 & 0.908 & 0.858 & 0.822 & 0.918 & 0.842 & 0.862 & 7 \\
\hline & $\mathrm{C} 5$ & F18 & Storage space medical reserves. & 0.786 & 0.908 & 0.835 & 0.811 & 0.824 & 0.848 & 0.835 & 14 \\
\hline & C5 & F19 & $\begin{array}{lrr}\text { Residential facility } & \text { to } \\
\text { accommodate } & \text { additional } \\
\text { medical/non-medical } & \text { staff } \\
\text { (Bunkers/Dormitories). } & \\
\end{array}$ & 0.768 & 0.892 & 0.780 & 0.678 & 0.800 & 0.782 & 0.783 & 23 \\
\hline & $\mathrm{C} 5$ & F20 & $\begin{array}{l}\text { Covered/Semi Covered spaces } \\
\text { for temporary set ups. }\end{array}$ & 0.739 & 0.800 & 0.762 & 0.722 & 0.788 & 0.758 & 0.762 & 24 \\
\hline
\end{tabular}




\begin{tabular}{rlllllllllll}
\hline Domain & Id. no. & Sub-Category & & RII & RII & RII & RII & RII & RII & Mean RII & R \\
\hline C5 & F21 & $\begin{array}{l}\text { Dedicated department } \\
\text { disaster management. }\end{array}$ & for & 0.809 & 0.862 & 0.780 & 0.800 & 0.847 & 0.788 & 0.814 & 21
\end{tabular}

\section{CONCLUSION}

This paper presents a relative importance index (RII) for the assessment of resilience indicators of hospitals exposed to hydrological disasters. The RII is a qualitative index that considers stakeholders preferences to i. the design flexibility, ii. modularity of critical units, location of building services, iii. back-up systems that support the functioning of hospitals, iv. availability of healthcare workers with provision of extended residential facilities and v. adaptive spatial capacity to accommodate the surge. Each indicator is evaluated on a scale of 0 (least important) to 5 (most important). A methodology is provided for the simple estimation of the resilience indicator that draws upon design and planning principles in practice, academic interpretation of resilient design and expert's outlook.

The RII approach is tested for a stakeholder perception survey in India, wherein the ranking method is used to assess the importance levels. The RII analysis for the three domains of hospital building show a high functional vulnerability of locating the building services for uninterrupted supply of medical services in critical units. These findings can help making decision framework for early interventions for improving the functional resilience of hospitals.

\section{LIMITATION AND WAY FORWARD}

The scope of this research paper is limited to large scale hospitals in the urban context. These hospitals are inclusive of tertiary care hospitals, trauma centres, multi-speciality hospitals, referral hospitals and research centres with bed facilities. The identified indicators address the resilience attributes against hydrological and climatic disasters in India.

\section{ACKNOWLEDGEMENT}

The corresponding authors(s) are thankful to the respondents of the survey and the Department of Architecture, School of Planning and Architecture (SPA), Delhi for supporting us with adequate resources. Extended gratitude towards the contribution and guidance of the faculty members in the Department of Building Engineering and Management, SPA Delhi.

\section{AUTHORS CONTRIBUTION}

This paper is an excerpt from the Ph.D thesis of the first author. The corresponding two authors have shared their inputs through organizing stakeholder's consultation workshop for the purpose of data collection.

\section{REFERENCES}

1. Murray, V., \& Ebi, K. L. (2012). IPCC special report on managing the risks of extreme events and disasters to advance climate change adaptation (SREX).

2. National Disaster Management Authority (NDMA). (2008). National Disaster Management GuidelinesManagement of Floods. New Delhi.

3. NDMA. (2016). Guidelines on Hospital Safety. National Disaster Management Authority, GoI. https://nidm.gov.in/PDF/pubs/NDMA/18.pdf

4. Carballo, M., Daita, S., \& Hernandez, M. (2005). Impact of the Tsunami on healthcare systems.

5. Achour, N., Miyajima, M., Pascale, F., \& Price, A. D. (2014). Hospital resilience to natural hazards: classification and performance of utilities. Disaster prevention and management, 23(1). https://doi.org/10.11 08/DPM-03-2013-0057

6. National Disaster Management Authority-Newsletter. (2021, May 14). Double trouble cyclone tauktae and cyclone yaas. National Disaster Management Authority, Government of India. https://ndma.gov.in/sites/defa ult/files/PDF/Newsletters/Aapda-Samvaad-Issue-May-2021.pdf

7. Centers for Disease Control and Prevention. (2018). Public health emergency preparedness and response capabilities: National standards for state, local, tribal, and territorial public health. Atlanta, GA: US Department of Health and Human Services. 
8. Kumar, P., Sahu, N. C., \& Kumar, S. (2021). Natural disasters and income inequality in South Asia: an FGLS panel analysis. Critical Perspectives on Emerging Economies. Contributions to Economics. Springer, Cham, 27-39.

9. Spencer, C., Majeed, S., McArdle, D., Parkinson, D., \& Archer, F. (2019). Long-term disaster resilience: A research gap. Prehosp. Disaster Med, 34(1), s21. https://doi.org/10.1017/S1049023X19000608

10. Hojat, M. (2008, July). A survey of hospital disaster management in medical science universities of Tehran2005. In The 19th International Nursing Research Congress Focusing on Evidence-Based Practice.

11. Back, M. H., \& Kim, H. J. (2010). Analysis of hospital disaster in South Korea from 1990 to 2008. Yonsei medical journal, 51(6), 965-970. https://doi.org/10.3349/ymj.2010.51.6.965

12. Nekoie-Moghadam, M., Kurland, L., Moosazadeh, M., Ingrassia, P. L., Della Corte, F., \& Djalali, A. (2016). Tools and checklists used for the evaluation of hospital disaster preparedness: a systematic review. Disaster medicine and public health preparedness, 10(5), 781-788. https://doi.org/10.1017/dmp.2016.30

13. Department of Homeland Security. (2007). Guidelines for improving Hospital Safety. FEMA. https://www.fema.gov/sites/default/files/2020-08/fema577_design_guide_improving_hospital_safety_2007.pdf

14. Department of Homeland Security (DHS), Government of US. (2012). Sector Resilience Report. Department of Homeland Security. https://www.hsdl.org/?view\&did=763639

15. FEMA. (2013). Reducing Flood Effects in Critical Facilities.

16. FEMA. (n.d.). Columbus Regional Health-Flood of 2008.

17. FEMA. (n.d.). 2020 Mitigation Best Practises.

18. World Health Organization. (2015). Hospital Safety Index- Guide for Evaluators WHO.

19. Floods in the WHO European Region- Health Effects and their prevention WHO (2013).

20. World Health Organization. (2014). Floods and health- Fact sheets for health professionals.

21. World Health Organization. (2015). Comprehensive Safe Hospital Framework.

22. PAHO. (2014). Smart Hospitals Toolkit- Cost Benefit Analysis.

23. Jacques, C. C., McIntosh, J., Giovinazzi, S., Kirsch, T. D., Wilson, T., \& Mitrani-Reiser, J. (2014). Resilience of the Canterbury hospital system to the 2011 Christchurch earthquake. Earthquake spectra, 30(1), 533-554. https://doi.org/10.1193/032013EQS074M

24. Liu, M., Anbumozhi, V. Application of supply chain approach to improving hazard-resilient health services: framework analysis for ASEAN and options of implementation. J. Soc. Econ. Dev. (2021).

25. Rodrigues Leal Moitinho De Almeida, M. (2021). Fostering hospital resilience to disasters: lessons from a tertiary hospital in Nepal (Doctoral dissertation, UCL-Université Catholique de Louvain).

26. Yusoff, N. A., Shafii, H., \& Omar, R. (2017, November). The impact of floods in hospital and mitigation measures: A literature review. In IOP Conference Series: Materials Science and Engineering (Vol. 271, No. 1, p. 012026). IOP Publishing.

27. Zhong, S., Clark, M., Hou, X. Y., Zang, Y., \& FitzGerald, G. (2014). Validation of a framework for measuring hospital disaster resilience using factor analysis. International journal of environmental research and public health, 11(6), 6335-6353. https://doi.org/10.3390/ijerph110606335

28. Cimellaro, G. P. (2016). Urban resilience for emergency response and recovery. Fundamental Concepts and Applications. https://doi.org/10.1007/978-3-319-30656-8

29. Sharma, S. K., \& Sharma, N. (2020). Hospital preparedness and resilience in public health emergencies at district hospitals and community health centres. Journal of Health Management,22(2), 146-156. https://doi.org/10.1177/0972063420935539

30. PAHO. (2014). Smart Hospitals Toolkit- Cost Benefit Analysis.

31. Krishnan, S., \& Patnaik, I. (2020). Health and disaster risk management in India. Public Health and Disasters, 155-184. https://doi.org/10.1007/978-981-15-0924-7_11

32. Stone, T., Banks, J., Brant, H., Kesten, J., Redfern, E., Remmers, A., \& Redwood, S. (2020). The introduction of a safety checklist in two UK hospital emergency departments: A qualitative study of implementation and staff use. Journal of clinical nursing, 29(7-8), 1267-1275. https://doi.org/10.1111/jocn.15184

33. TANGO International. (2018). Methodological Guide: A Guide for Calculating Resilience Capacity. Produced by TANGO International as part of the Resilience Evaluation,Analysis and Learning (REAL) Associate Award.

34. Kotrlik, J. W. K. J. W., \& Higgins, C. C. H. C. C. (2001). Organizational research: Determining appropriate sample size in survey research appropriate sample size in survey research. Information technology, learning, and performance journal, 19(1), 43.

35. Aibinu, A. A., \& Jagboro, G. O. (2002). The effects of construction delays on project delivery in Nigerian construction industry. International journal of project management, 20(8), 593-599. https://doi.org/10.1 $\underline{016 / \mathrm{S} 0263-7863(02) 00028-5}$ 